\section{Effects of Temperature and Salinity on Survival Time of the Newly Hatched Threeline Grunt Parapristipoma trilineatum*1}

Short Paper

Temperature and salinity are factors which have a major effect on the survival of marine teleosts. This is the second paper concerning the effects of these factors on early development of the threeline grunt. In the previous paper, ${ }^{1)}$ percent of total hatching of the eggs was described.

The larvae were obtained soon after hatching from the eggs which had been incubated at $23.3 \pm 0.5^{\circ} \mathrm{C}$ and $33.4 \%$ salinity, nearly equal to the values at the time of spawning. Total body length was $2.22 \pm 0.07 \mathrm{~mm}$. Experimental design was a 2 factor $7 \times 3$ factorial (Fig. 1). The highest salinity was prepared by mixing natural sea water and synthetic sea salts. An average of 28 (range 21-40) larvae was put into each $30 \mathrm{~mm}$ diameter test tube with $50 \mathrm{~m} l$ water. Two replicates of the three tubes with each salinity were placed in the seven test temperature baths, constantly controlled within $\pm 0.3^{\circ} \mathrm{C}$. When the tubes were checked every about six h, any larvae which had sunk and of which the heart had stopped beating were considered dead. Time to $50 \%$ mortality was calculated by interpolation and shown as the median survival time (MST).

The experimental data are shown in Fig. 1. The relationship between MST and variables $(T, S)$ was calculated by the method of orthogonal polynomial, and consequently expressed by the second order equation:

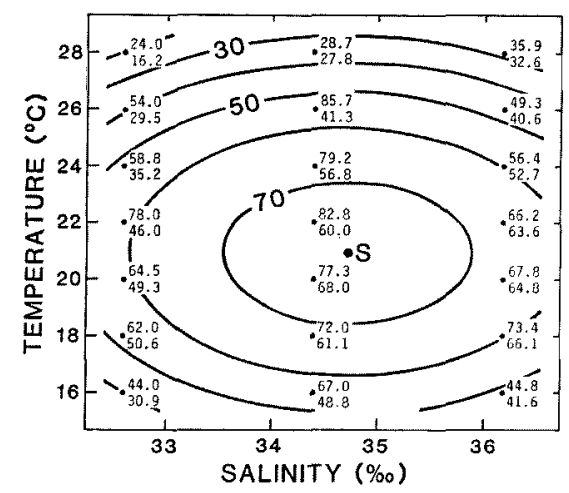

Fig. 1. Response surface showing the isopleths of MST (h). The array of points and figures locates the experimental combinations and data of MST.

\footnotetext{
(Accepted September 26, 1984)

*11サキ仔魚の生存時關に及ぼす水温と塩分の影帮。

*2 柏木正章 - 山田直博 - 岩井寿夫: 三重大学水産学 部, 津市江戸椅 2-80.
}

Table 1. Analysis of variance for the data

\begin{tabular}{lrrrc}
\hline \multicolumn{1}{c}{ Source } & \multicolumn{1}{c}{ SS } & DF & \multicolumn{1}{c}{ MS } & \multicolumn{1}{c}{ F } \\
\hline Treatments & $9,155.26$ & 20 & 457.76 & $2.96^{* 2}$ \\
Temperature & $6,963.08$ & 6 & $1,160.51$ & $7.52^{* 2}$ \\
Salinity & $1,629.68$ & 2 & 814.84 & $5.28^{* 1}$ \\
Interaction & 562.50 & 12 & 46.88 & 0.30 \\
\hline Regression & $8,356.39$ & 5 & $1,671.28$ & $10.83^{* 2}$ \\
$\quad$ Linear & $2,307.12$ & 2 & $1,153.56$ & $7.47^{* 2}$ \\
$\quad$ Quadratic & $6,049.27$ & 3 & $2,016.42$ & $13.06^{* 2}$ \\
$\quad$ Remainder & 798.87 & 15 & 53.26 & 0.34 \\
\hline Residual & $3,242.27$ & 21 & 154.39 & \\
Total & $12,397.53$ & 41 & & \\
\hline
\end{tabular}

Asterisk: significant ( $\left.{ }^{* 1} p<0.05,{ }^{* 2} p<0.01\right)$.

$$
\mathrm{MST}=-4441.58+32.55 \mathrm{~T}+240.52 \mathrm{~S}-0.78 \mathrm{~T}^{2}-3.46 \mathrm{~S}^{2}
$$

but where the term of interaction, TS, was omitted because it was statistically insignificant as shown in ANOVA (Table 1). ${ }^{2}$ The longest MST was $77.9 \mathrm{~h}$ at $20.9^{\circ} \mathrm{C}$ combined with $34.7 \%$ (point $\mathrm{S}$ in Fig. 1).

On the effects of temperature and salinity on the newly hatched teleost larvae, there are few reports about the survival time. Although several studies on the efficient yolk utilization have been made, ${ }^{3)}$ the accuracy of measurement is not satisfactory for the small size larvae such as the present species. Generally, the teleost larvae during the yolk sac stage utilize the yolk as a energy source for metabolism and growth, but after the final resorption of it they starve to death if no external food is available. Therefore, the survival time after hatching is closely related to the efficient yolk utilization, and depends strongly on the environments. It can be considered that the temperaturesalinity combination for the longest MST is the optimum. The previous paper ${ }^{1)}$ noted for the eggs that the maximum percent of total hatching (i.e., optimum) was found at $22.4^{\circ} \mathrm{C}$ combined with $34.2 \%$. There is not great difference in the optima between eggs and newly hatched larvae.

We thank Mr. S. Kimura, of the Fisheries Research Laboratory, for providing us the material.

Masaaki KashiwaGi*2, Naohiro YAMADA,*2 and Toshio IWaI*2

Faculty of Fisheries, Mie University, Tsu 514, Japan.

\section{References}

1) M. Kashiwagi, N. Yamada, Y. Okada, F. Nakamura, S. Kimura, and T. IwaI: Bull. Fac. Fish. Mie Univ., No. 11, 1-13 (1984).

2) C.I. Buiss: Statistics in Biology, Vol. II, McGrowHill, New York, 1970, pp. 427-433.

3) J. H. S. BLAXTER: in "Fish physiology" (ed. by W. S. Hoar and D. J. Randall), Vol. 3, Academic Press, New York, 1969, pp. 178-241. 